\title{
Fatty acids in an estuarine mangrove ecosystem
}

\author{
Nabeel M. Alikunhi ${ }^{1}$, Rajendran Narayanasamy ${ }^{1}$ \& Kathiresan Kandasamy ${ }^{1}$ \\ 1. Centre of Advanced Study in Marine Biology, Annamalai University, Parangipettai, 608 502, Tamil Nadu, India; \\ kathirsum@rediffmail.com
}

Received 19-V-2009. Corrected 06-I-2010. Accepted 02-II-2010.

\begin{abstract}
Fatty acids have been successfully used to trace the transfer of organic matter in coastal and estuarine food webs. To delineate these web connections, fatty acid profiles were analyzed in species of microbes (Azotobacter vinelandii, and Lactobacillus xylosus), prawns (Metapenaeus monoceros and Macrobrachium rosenbergii) and finfish (Mugil cephalus), that are associated with decomposing leaves of two mangrove species, Rhizophora apiculata and Avicennia marina. The fatty acids, except long chain fatty acids, exhibit changes during decomposition of mangrove leaves with a reduction of saturated fatty acids and an increase of monounsaturated fatty acids. The branched fatty acids are absent in undecomposed mangrove leaves, but present significantly in the decomposed leaves and in prawns and finfish, representing an important source for them. This revealed that the microbes are dominant producers that contribute significantly to the fishes and prawns in the mangrove ecosystem. This work has proved the fatty acid biomarkers as an effective tool for identifying the trophic interactions among dominant producers and consumers in this mangrove. Rev. Biol. Trop. 58 (2): 577-587. Epub 2010 June 02.
\end{abstract}

Key words: mangroves, fish, microbes, fatty acid, biomarker.

Mangroves are one among the most productive ecosystems and their productivity is attributed to litter degradation and efficient recycling of nutrients, which are supplied by both autochthonous and allochthonous inputs from natural and anthropogenic sources (Heald 1971, Odum \& Heald 1975, Lee 1990, Kathiresan \& Bingham 2001). Microbial processing of litter is an important mechanism for preserving nutrients and energy in the mangrove ecosystem (Fell et al. 1975, Fell \& Master 1981, Raghukumar et al. 1994, Kathiresan \& Bingham 2001, Rajendran \& Kathiresan 2007). Mangrove litter of low nutritive value is decomposed and converted into nutrient-rich which serves as food for fishes (Odum 1971, Lee 1990, Kathiresan \& Bingham 2001, Rajendran \& Kathiresan 1998, 1999a, 2000, 2004 \& 2007, Ashton et al. 1999). The litter decomposition occurs typically in three, often-simultaneous phases: (i) leaching of soluble components; (ii) microbial oxidation of refractory components such as cellulose and lignin; and (iii) physical and biological fragmentation with microbial enrichment (Valiela et al. 1985). In these processes, the flow of carbon and nitrogen from primary producers to consumers takes place, but the flow is not clearly understood for the mangrove ecosystem.

Food web in mangroves is often under debate and contribution of the mangroves as primary producers is much clear even when advanced techniques like stable isotopes have been used (Canuel et al. 1995, Bouillon et al. 2002). Fatty acid trophic marker (FATM) concept is based on the observation that marine primary producers lay down certain fatty acid patterns that may be transferred conservatively to primary consumers (Dalsgaard et al. 2003). Fatty acids can be specific to each species and 
are often used as food web markers (Kiyashko et al. 1998, Kharlamenko et al. 2001, Dalsgaard et al. 2003). This FATM concept has been successfully used to trace the transfer of organic matter in coastal and estuarine food webs (Kharlamenko et al.1995, Napolitano et al.1997, Meziane \& Tsuchiya 2000, Bachock et al. 2003, Hall et al. 2006). However, such studies are not available for estuarine mangrove ecosystems and associated flora and fauna of India. To fill this lacuna, the present study was made to trace the potential of fatty acids as biomarkers in identifying the trophic interactions, in such a way to delineate the food web in mangrove ecosystem.

\section{MATERIALS AND METHODS}

Experimental work: The present study was conducted from January to March 2007, post monsoon season of the study area. Senescent leaves of Rhizophora apiculata Blume and Avicennia marina (Forsk). Vier were collected from a mangrove forest, growing along the Vel-

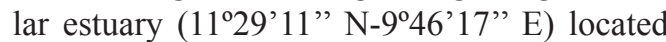
in southeast coast of India. The leaves were shade-dried and packed at $50 \mathrm{~g}$ in each of six nylon bags $(15 \times 10 \mathrm{~cm})$ and mesh size of $2 \mathrm{~mm}$. Pits were constructed linearly in the inter-tidal mangrove area with an equi-distance of $1 \mathrm{~m}$ and a dimension of $1 \times 1 \times 1 \mathrm{~m}$. The temperature during the study period varied between $29^{\circ} \mathrm{C}$ and $34^{\circ} \mathrm{C}$. The bags containing the leaves of three different species were submerged separately in each pit and one pit was kept as control (without any mangrove leaves). Three replicates for all the groups of pits were also maintained. Each bag was submerged in water by placing a stone weighing $0.25 \mathrm{~kg}$ inside the bag. The inner side of each pit was covered with nylon net of $2 \mathrm{~mm}$ mesh size to trap the juvenile fishes. This experiment was conducted for 70 days. Fishes attracted towards the litter bags were collected daily during the time of low tide by lifting the inner net.

Collection and processing of microbes: For microbial analysis, the decomposing leaf samples were taken randomly from each nylon bag during 0, 20, 30, 40, 50, 60 and 70 days of experiment. They were cut in to small pieces and were washed thoroughly in sterilized seawater in order to remove debris on the leaves. For enumeration of total colony forming units, the Zobell's marine agar medium was used for total heterotrophic bacteria (THB) and the Winogradsky's medium for azotobacters. All the media components were purchased from Hi-media Chemicals, Mumbai, India. The microbes were enumerated by adopting spread plate method. The plates were incubated in an inverted position at $28 \pm 2^{\circ} \mathrm{C}$. All the determinations were carried out in triplicates. After the incubation period of 2 to 3 days for THB and 7 to 10 days for azotobacters, the colonies were counted and calculated for colony forming units per gram leaf tissue. The dominant microbial colonies were identified based on morphological and biochemical characters (Buchanan \& Gibbons 1974).

Collection and processing of prawns, finfish and mangrove leaves: The collected samples of prawns, finfish and mangrove leaves were brought to laboratory and washed in the tap water. The prawns and finfish were identified using standard guidelines (Fischer \& Bianchi 1984, Paulpandian \& Ramasamy 1991) and were used for further studies.

Analysis of fatty acids: Fatty acid profile was analyzed for the mangrove leaves of $R$. apiculata and A. marina at different days of decomposition, and also for the dominant species of microbes and prawns and finfish (muscles) associated with the decomposing mangrove leaves. Fatty acids were extracted by standard methods (Bligh \& Dyer 1959, Meziane \& Tsuchiya 2000). The extracts were saponified at $80^{\circ} \mathrm{C}$ for $90 \mathrm{~min}$ with a mixture of sodium hydroxide and methanol in a ratio of $1: 2$. The fatty acid methyl ester (FAME) was prepared and analyzed by using a gas chromatograph (Agilent-GC 6890N) equipped with flame ionization detector. Capillary column HP Ultra 2 with $2 \mathrm{~m}$ long and $0.2 \mathrm{~mm}$ inner diameter, coated with $5 \%$ phenyl methyl silaxane and $0.33 \mu \mathrm{m}$ thicknesses was used. The rate of hydrogen carrier gas flow was maintained at 
$30 \mathrm{ml} / \mathrm{min}$. Most of the FAME were identified by using a calibration standard software of MIDI. Some of FAME peaks were identified by comparing their retention times with those of authentic standards (Supelco Inc.).

Statistical analysis: To evaluate significance in fatty acid composition, one way ANOVA test followed by Post hoc test was used with the help of SPSS, Version 13.0 (SPSS, Illinois).

\section{RESULTS}

Fish and microbial counts: The trends in fishes and microbial counts with decomposing mangrove leaves are depicted in the Fig. 1 and 2. In general, fish groups increased towards decomposing leaves up to 40 days, and then declined (Fig. 1). A similar trend was also recorded with counts of total heterotrophic bacteria and azotobacters (Fig. 2). The prawns, finfish and microbes behaved similarly with increasing days of leaf decomposition up to 40 days in both species of mangroves, $R$. apiculata and A. marina.

Dominant species attracted towards the decomposing leaves were Metapenaeus monoceros, Macrobrchium rosenbergii, and Mugil cephalus that belong respectively to penaeid prawns, non-penaeid prawns and finfish. Two predominant species of microbes isolated from the decomposing mangrove leaves were Azotobacter vinelandii and Lactobacillus xylosus.

Changes of fatty acid groups during decomposition of mangrove leaves: Levels of fatty acid groups in the mangrove leaves of R. apiculata and A. marina at 0, 40 and 70 days of decomposition are shown in table 1 .
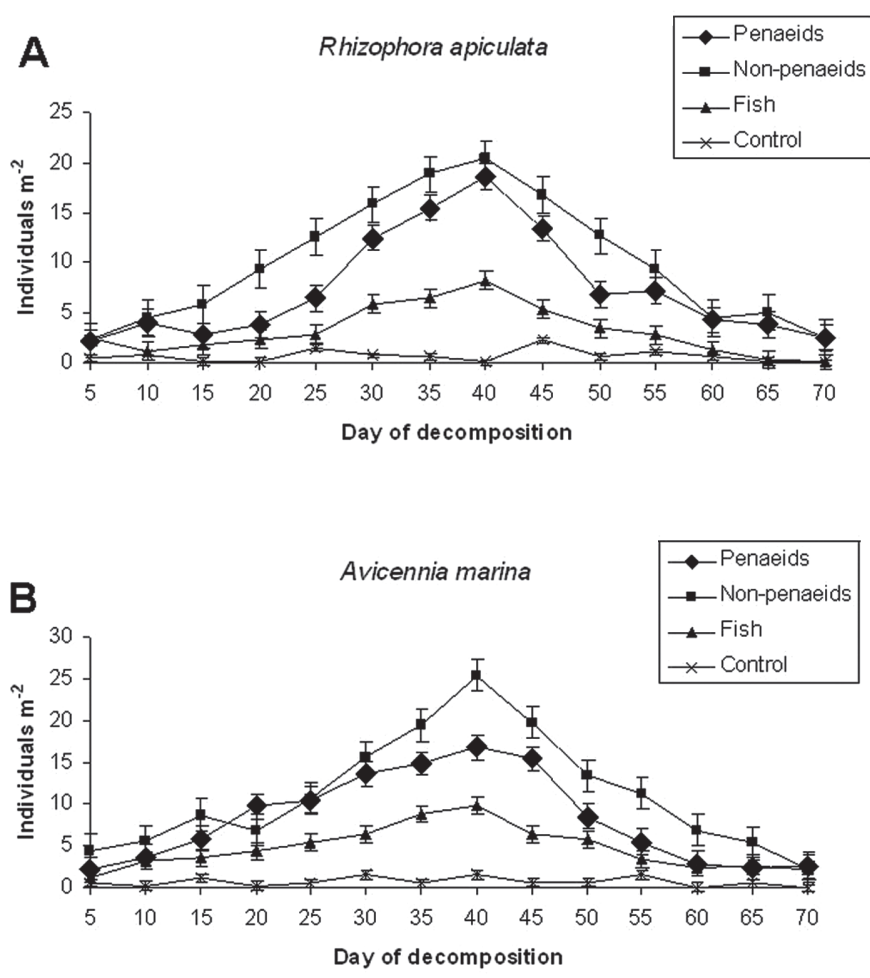

Fig. 1. Abundance of penaeids, non-penaeids and finfish at different days of leaf decomposition in two species of mangroves (A) Rhizophora apiculata; and (B) Avicennia marina. 

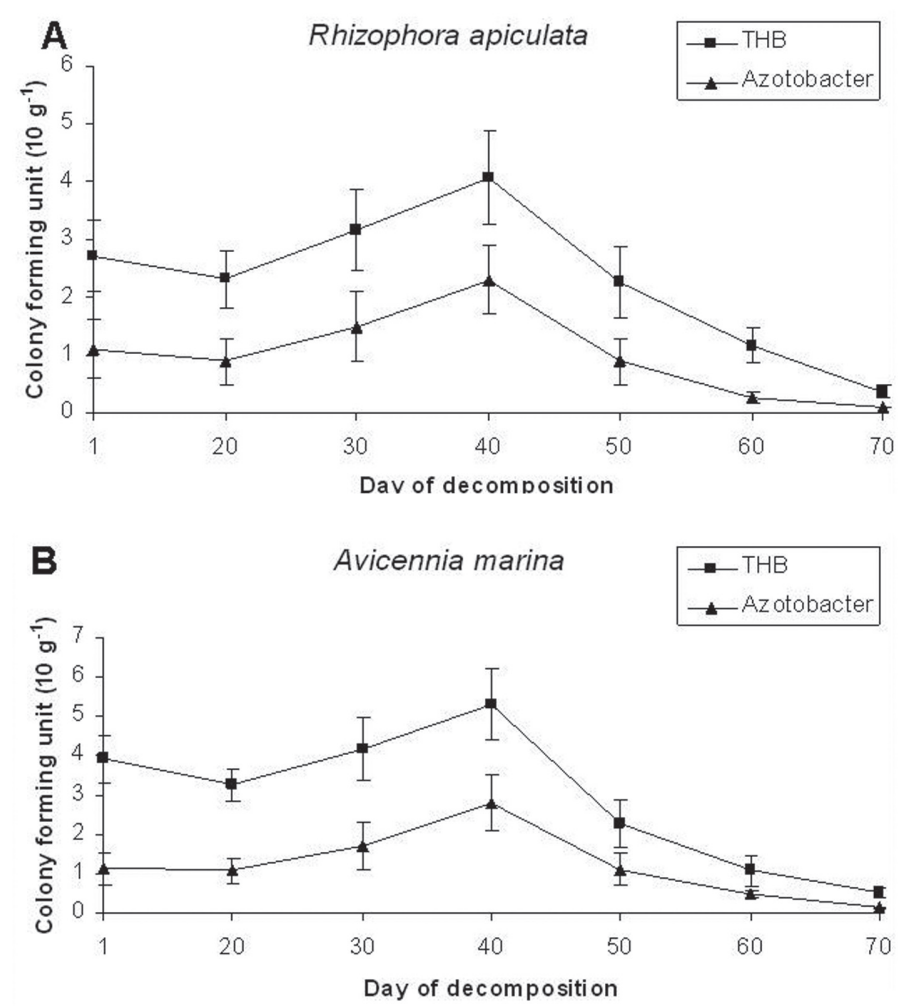

Fig. 2. Total heterotrophic bacteria (THB) and azotobacters at different days of leaf decomposition in two species of mangroves (A) Rhizophora apiculata; and (B) Avicennia marina, expressed in colony forming units per gram leaf tissue.

Fatty acid groups varied significantly $(\mathrm{p}<0.05)$ with mangrove species. Among the fatty acid groups, saturated fatty acids were the most abundant one, which decreased significantly $(\mathrm{p}<0.05)$ with increasing days of decomposition. Long chain fatty acids did not show any significant change during leaf decomposition. Monounsaturated fatty acids were significantly $(p<0.05)$ higher in decomposed leaves than fresh leaves. Branched fatty acids exhibited a different trend: they were significantly higher $(p<0.05)$ at 40 days of decomposition than at 70 days and/or fresh leaves in both mangrove species. Polyunsaturated fatty acids decreased significantly $(\mathrm{p}<0.05)$ with leaf decomposition only in the case of A. marina, but, there was no such trend in $R$. apiculata.

\section{Levels of fatty acid groups in fishes and} microbes: Levels of fatty acid groups in prawns, finfish and microbes associated with decomposing leaves of two mangrove species is shown in table 1 . The fishes and microbes contained high levels of branched chain fatty acids followed by saturated fatty acids. However, these species were devoid of detectable quantities of long chain fatty acids. Polyunsaturated fatty acid groups were higher in fishes than microbes; in contrast, saturated fatty acid group was higher in microbes than fishes. The monounsaturated fatty acid group did not show any significant variation between microbes and fishes.

Fatty acid biomarkers: Levels of fatty acid biomarkers present in microbes, prawns 


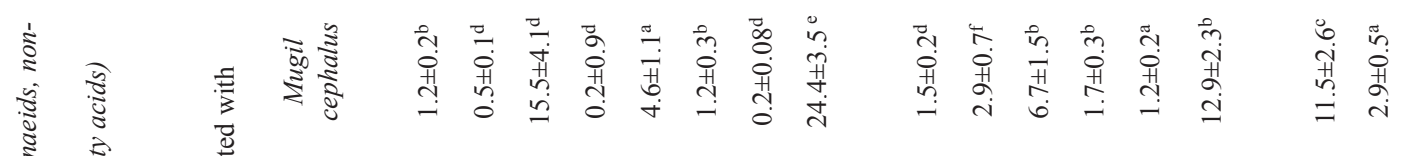

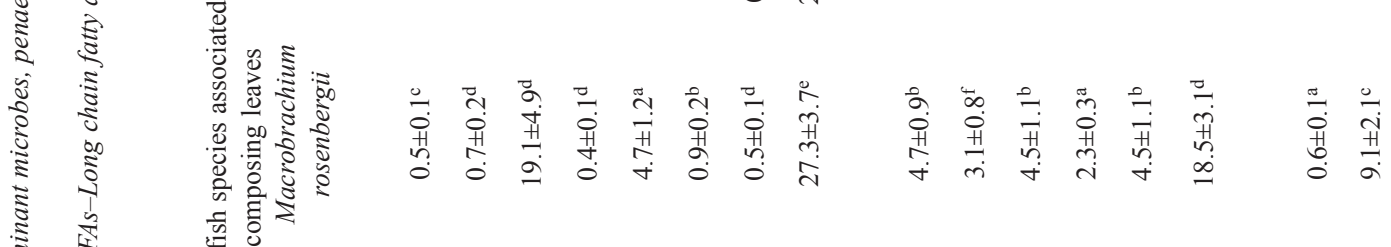

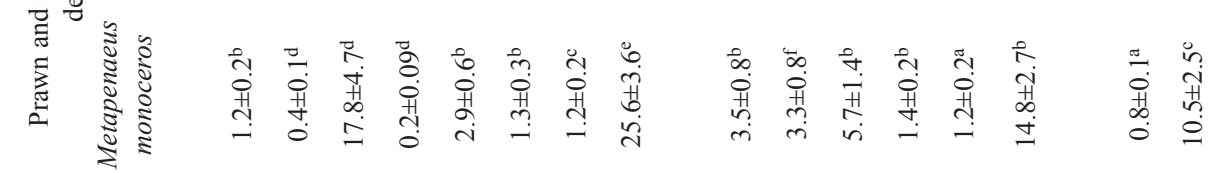

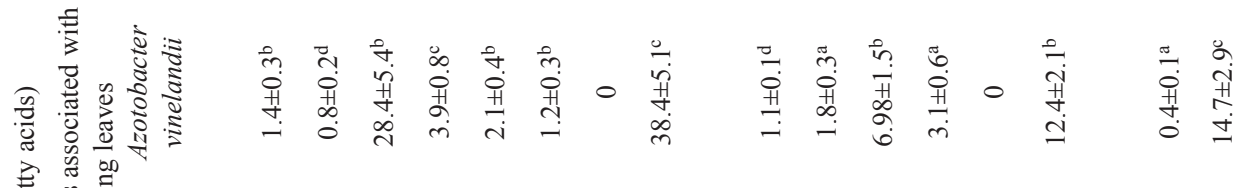

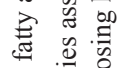

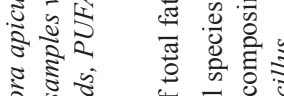

ㅇำ

के :

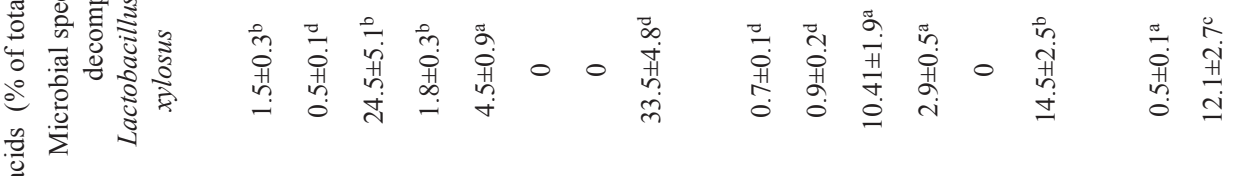
पू

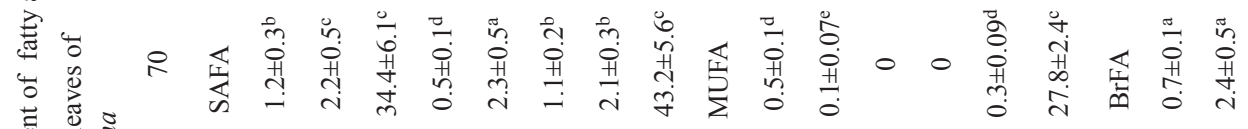

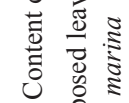

范范

造 
and fishes are shown in table 2 . The bacterial biomarkers, namely 15:0 ISO, 15:0 ANTEISO, 17:0 ISO, 17:0 ANTEISO and Vaccenic acid $(18: 1 \mathrm{n}-7)$ were abundantly present in prawns and fish. However, other fatty acid biomarkers which are specific to seaweeds [Oleic acid, (18:1 n-9)], diatoms [Eicosapentaenoic acid (20:5 $\mathrm{n}-3)$ ], and seagrasses [Linoleic acid, (18:2 n-6) and $\alpha$-Linolenic acid, (18:3 n-3)] were present at low levels in the prawns and fish.

\section{DISCUSSION}

Mangroves are rich in microbes especially during the process of leaf decomposition (Ravikumar 1995, Rajendran \& Kathiresan 2004, 2007, Kathiresan \& Masilamani 2005). In the present study we observed an abundance of Azotobacter vinelandii and Lactobacillus xylosus in the decomposing mangrove leaves, besides Metapenaeus monoceros, Macrobrchium rosenbergii and Mugil cephalus. These fishes are well-known as a detritivorous organisms commonly occurring in the mangrove waters (Rajendran \& Kathiresan 1998, 1999a, 1999b). Azotobacters are capable of fixing nitrogen and building protein in the form of microbial biomass in the decomposing leaves of mangroves, thereby enhancing palatability of detritus food to the fishes (Ravikumar 1995, Kathiresan \& Masilamani 2005). The genus Lactobacillus is a beneficial microbial flora, present in guts of the fishes (Fuller 1989).

Lipids are carbon-rich compounds, serving as an important source of energy and essential nutrients for survival and growth of all organisms. They are relatively easy to metabolize when consumed as part of the animal's diets (Hazel et al. 1991, Parrish 1998, Parrish et al. 2000, Dalsgaard et al. 2003). Fatty acids of the lipids are transferred from primary producers to higher trophic levels without significant change and hence they are used as biomarkers (Parrish et al. 2000, Dalsgaard et al. 2003). Previous studies have used fatty acids such as 15:0 ISO, 15:0 ANTEISO, 17:0 ISO, 17:0 ANTEISO and 18:1n-7 as biomarkers for the bacteria (Rajendran et al.1993),
$20: 5(\mathrm{n}-3), \quad 16: 1 / 16: 0>1.6, \quad \sum 16 / \sum 18>2$, and $20: 5 n-3 / 22: 6 n-3>1$ for the diatoms, $22: 6 n-3$ and $20: 5 n-3 / 22: 6 n-3<1$ for the dinoflagellates (Parrish et al. 2000), 20:5n-3/20:4n-6>10 for the red algae (Khotimchenko \& Vaskovsky 1990), 20:1+22:1 for the zooplankton (FalkPetersen et al. 2002), 18:2n-6+18:3n-3 for the seagrass (Kharlamenko et al. 2001), and, long chain fatty acids with more than 24 carbons for the mangroves and other vascular plants (Wannigama et al. 1981). The present study recorded that the tissues of the consumer fish and prawns were enriched with the bacterial fatty acid biomarkers such as 15:0 ISO, 15:0 ANTEISO, 17:0 ISO, 17:0 ANTEISO and 18:1n-7. However, the biomarkers of seaweeds (18:1 n-9), diatoms (20:5 n-3), and seagrasses $(18: 2 n-6+18: 3 n-3)$ were present only in minor quantities in the fish and prawns analyzed. Long chain fatty acids, the biomarker of vascular plants like mangroves, could not be detected in the fishes (Table 2) as they are not consumed by fishes due to their complex structure (Mfilinge et al. 2003). Thus, this study reveals that the consumer fishes contain more fatty acids of bacterial origin than those of other producers in the mangrove ecosystem.

Composition of fatty acids changed significantly in the decomposing leaves of mangroves, from saturated straight chain fatty acids to monounsaturated fatty acids and more Branched Fatty Acids (BrFAs) (Table 1). These BrFAs were absent in fresh mangrove leaves, but detected during leaf decomposition and this was due to the growth of microbes that were rich in BrFAs. However, there was no change in the long chain fatty acids present in the mangrove leaves on decomposition (Table 1).

The branched chain fatty acids (15:0 and 17:0 ISO and ANTEISO) and the monounsaturated fatty acids (18:1 n-7) are known to be synthesized predominantly by bacterial communities (Jeffries 1972, Volkman et al. 1980) and consequently, they are useful as bacterial biomarkers and indicators of bacterial biomass (Parkes 1987). Levels of the bacterial fatty acids were higher in 40 days decomposed leaves than fresh leaves and/or 70 days 


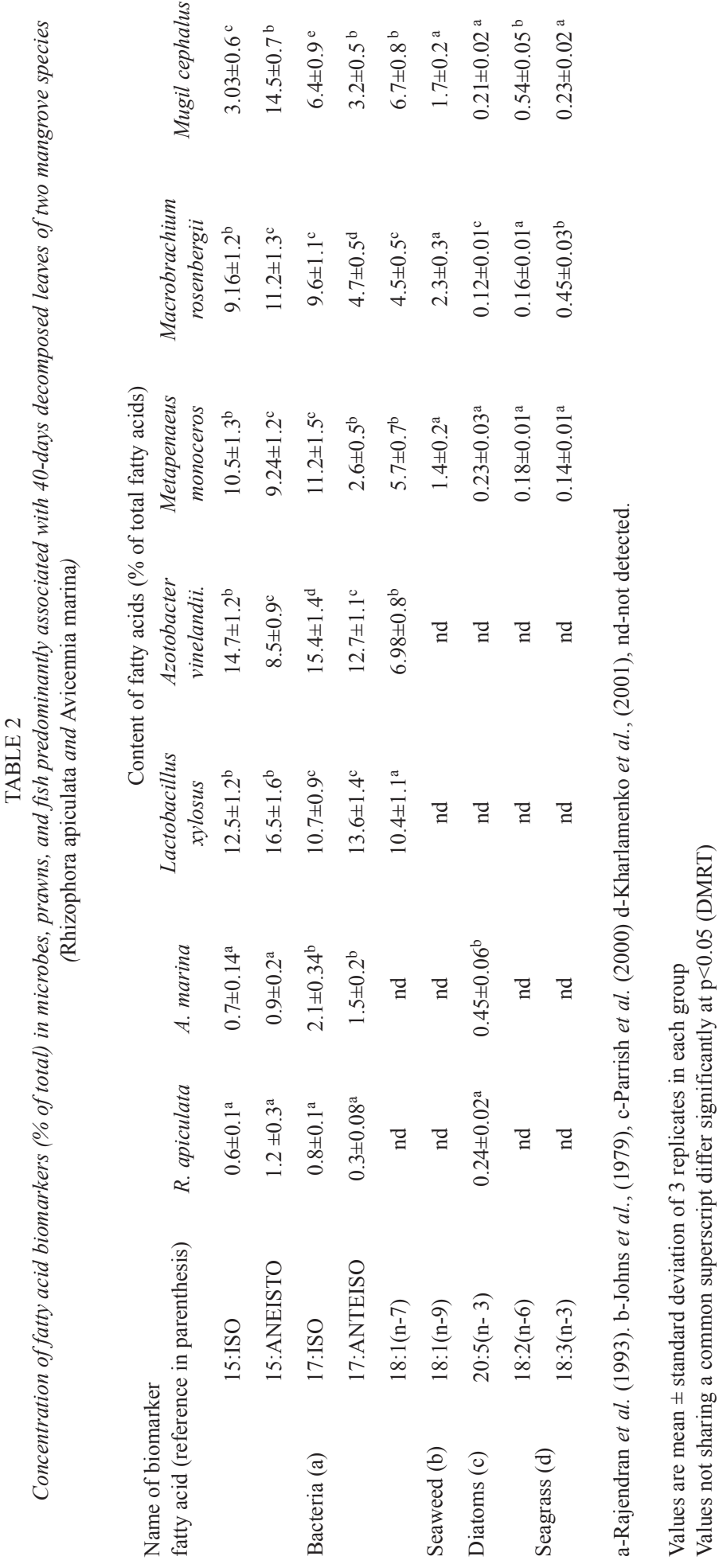


decomposed ones. This could be attributed to the bacterial abundance in those leaves (Fig. 2). The fish assemblage was also higher with 40 days decomposed leaves. This link could be attributed to enrichment of microbial biomass coupled with enhancement of nutrients of the decomposing leaves, required for diet of the detritivorous fish (Rajendran \& Kathiresan 2000, 2007).

Long chain fatty acids (LCFAs) with more than 24 carbon atoms are synthesized only by vascular plants (Hogg \& Gillan 1984), and consequently the LCFAs can be used as biomarkers of vascular plant origin in animal tissues. The LCFAs are present mainly in epicuticular wax of the vascular plants including mangroves (Meziane et al.2002, Mfilinge et al. 2003). In the present study, LCFAs were found as common constituent in the leaves of the two mangrove species at all the days of decomposition (Table 1). There was no significant change in LCFAs during mangrove leaf decomposition as they are resistant to microbial transformation (Wannigama et al. 1981, Mfilinge et al. 2003). The LCFAs could not be detected in the tissues of prawns and fish. Thus the LCFAs do not contribute to the consumer fishes, and this fact makes them weak biomarkers. In support of this, Hall et al. (2006) have observed that crabs do not assimilate the LCFAs due to lack of necessary enzymes for break down of LCFAs and hence release them through feces.

As microorganisms usually do not accumulate large lipid reserves, fatty acid trophic marker (FATM) may be of less relevance to trace trophic link in ecosystems. However, despite their lack of storage lipids, heterotrophic bacteria, which contribute significantly to these systems, are still recognizable by specific fatty acids. Considering the fast turnover rates of microorganisms, Dalsgaard et al. (2003) therefore hypothesize that FATM may help resolve trophic interactions in microbial loop food webs and they support the strengthening of fatty acid research in this area, also by Strom (2000), recognizing the importance of these systems in the global carbon budget. The present study has also reiterated that the bacterial fatty acids are important component which contribute significantly to the food web of mangrove ecosystem.

\section{ACKNOWLEDGMENTS}

The authors are thankful to authorities of Annamalai University for providing facilities and to Ministry of Environment \& Forests, Govt. of India, New Delhi for providing financial assistance.

\section{RESUMEN}

Los ácidos grasos se han utilizado con éxito para estudiar la transferencia de materia orgánica en las redes alimentarias costeras y estuarinas. Para delinear las interacciones tróficas en las redes, se analizaron perfiles de ácidos grasos en las especies de microbios (Azotobacter vinelandii y Lactobacillus xylosus), camarones (Metapenaeus monoceros y Macrobrachium rosenbergii) y peces (Mugil cephalus), que están asociadas con la descomposición de las hojas de dos especies de mangle, Rhizophora apiculata y Avicennia marina. Los ácidos grasos, con excepción de los de cadena larga, exhiben cambios durante la descomposición de las hojas de mangle, con una reducción de los ácidos grasos saturados y un aumento de los monoinsaturados. Los ácidos grasos ramificados están ausentes en las hojas de mangle sin descomponer, pero presentes de manera significativa en las hojas descompuestas, en camarones y peces, representando una fuente importante para ellos. Esto revela que los microbios son productores dominantes que contribuyen significativamente con los peces y camarones en el ecosistema de manglar. Este trabajo demuestra que los marcadores biológicos de los ácidos grasos son una herramienta eficaz para la identificación de las interacciones tróficas entre los productores dominantes y consumidores en este manglar.

Palabras clave: manglares, peces, microbios, ácidos grasos, marcadores biológicos.

\section{REFERENCES}

Ashton, E.C., P.J. Hogarth \& R. Ormond. 1999. Breakdown of mangrove litter in a managed mangrove forest in Peninsular Malaysia. In Diversity and Function in Mangrove Ecosystems. Hydrobiologia 413: 77-88.

Bachock, Z., P.L. Mfilinge \& M. Tsuchiya. 2003. The diet of the mud clam Geloina coaxans (Mollusca, Bivalvia) as indicated by fatty acid markers in a subtropical 
mangrove forest of Okinawa, Japan. J. Exp. Mar. Biol. Ecol. 292: 187-197.

Bligh, E.G. \& J. Dyer. 1959. A rapid method of total lipid extraction and purification. Can. J. Biochem. Physiol. 37: 922-930.

Bouillon, S., A.V. Raman, P. Dauby \& F. Dehairs. 2002. Carbon and nitrogen stable isotope ratios of sub tidal benthic invertebrates in estuarine mangrove ecosystem (Andhra Pradesh, India). Estuar. Coast. Shelf. Sci. 54: 901-913.

Buchanan, R.E. \& N.E. Gibbons. 1974. Bergey's manual of determinative bacteriology. The Williams and Wilkins Company, Baltmore.

Canuel, E.A., J.E. Cloern, D.B. Ringelberg, J.B. Guckert \& G.H. Rau. 1995. Molecular and isotopic tracers used to examine sources of organic matter and its incorporation into the food webs of San Francisco Bay. Limnol. Oceanogr. 40: 67-81.

Dalsgaard, J., M. John, G. Katter, D. Muller-Navarra \& W. Hagen. 2003. Fatty acid trophic markers in the pelagic marine environment. Adv. Mar. Biol. 46: 225-340.

Falk-Petersen, S., T.M. Dahl, C.L. Scott, J.R. Sargent, B. Gulliksen, S. Kwasniewski, H. Hop \& R. Millar. 2002. Lipid biomarkers and trophic linkages between ctenophores and copepods in Svalbard waters. Mar. Ecol. Prog. Ser. 227: 187-194.

Fischer, W. \& G. Bianchi. 1984. Species identification sheets for fishery purpose. FAO. Food and Agriculture organization of the United Nations, Rome.

Fell, J.W. \& I.M. Master. 1981. The association and potential role of fungi in mangrove detrital systems. Bot. Mar. 23: 257-263.

Fell, J.W., R.C. Cefalu, I.M. Master \& A.S. Tallman. 1975. Microbial activities in the mangrove Rhizophora mangle leaf detrital system, p. 661-679. In G.E. Walsh, S. Snedakar, H.J. Teas (eds.). Proceedings of International Symposium Biology and Management of Mangroves. Gainesville, University of Florida.

Fuller, R. 1989. Probiotics in man and animal. J. Appl. Bacteriol. 66: 365-378.

Hall, D., S.Y. Lee \& T. Meziane. 2006. Fatty acids as trophic tracers in an experimental estuarine food chain: Tracer transfer. J. Exp. Mar. Biol. Ecol. 336: 42-53.

Hazel, J.R., E.E. Williams, R. Livermore \& N. Mozingo. 1991. Thermal adaptation in biological membranes, functional significance of changes in phospholipids molecular species composition. Lipids 26: 277-282.

Heald, E.J. 1971. The production of organic detritus in a south Florida estuary. Sea Grant Tech. Bull. Miami Univ. 6-110.

Hogg, R. \& F. Gillan. 1984. Fatty acids, sterols and hydrocarbons in the leaves from eleven species of mangrove. Phytochemistry 23: 93-91.

Jeffries, P.H. 1972. Fatty acid ecology of tidal marsh. Limnol. Oceanogr. 17: 433-440.

Johns, R.B., P.D. Nichols \& G.J. Perry. 1979. Fatty acid composition of ten algae from Australian waters. Phytochemistry 18: 799-802.

Kathiresan, K. \& B.L. Bingham. 2001. Biology of mangroves and mangrove eco systems. Adv. Mar. Biol. 40: $81-251$.

Kathiresan, K. \& M. Masilamani. 2005. Evaluation of beneficial bacteria from mangrove soil. Bot. Mar. 49: $86-88$.

Kharlamenko, V.I., N.V. Zhukova, S.V. Khotimchenko, V.I. Svetashev \& G.M. Kamenev. 1995. Fatty acids as markers of food sources in a shallow water hydrothermal ecosystem (Kraternaya Bight, Yankich Island, Kurile Islands). Mar. Ecol. Prog. Ser. 120: 231-241.

Kharlamenko, V.I., S.I. Kiyashko, A.B. Imbs \& D.I. Vyshkvartzev. 2001. Identification of food sources of invertebrates from the seagrass Zostera marina community using carbon and sulfur isotope ratio and fatty acid analyses. Mar. Ecol. Prog. Ser. 220: 103-117.

Khotimchenko, S.V. \& V.E. Vaskovsky. 1990. Distribution of $\mathrm{C}_{20}$ polyenoic fatty acids in red macrophytic algae. Bot. Mar. 33: 525-528.

Kiyashko, S.I., V.I. Kharlamenko \& A.B. Imbs. 1998. Stable isotope ratios and fatty acids as food source markers of deposit-feeding invertebrates. Russ. J. Mar. Biol. 24: 170-174.

Lee, S.Y. 1990. Primary productivity and particulate organic matter flow in an estuarine mangrove-wetland in Hong Kong. Mar. Biol. 106: 453-463.

Meziane, T. \& M. Tsuchiya. 2000. Fatty acids as tracers of organic matter in the sediment and web of a mangrove/intertidal flat ecosystem, Okinawa, Japan. Mar. Ecol. Prog. Ser. 200: 49-57.

Meziane, T., M.C. Sanabe \& M. Tsuchiya. 2002. Role of fiddler crab of a subtropical intertidal flat of 
sedimentary fatty acids. J. Exp. Mar. Biol. Ecol. 270 191-201.

Mfilinge, P.L., T. Meziane, Z. Bachok \& M. Tsuchiya. 2003. Fatty acids in decomposing mangrove leaves: microbial activity, decay and nutritional quality. Mar. Ecol. Prog. Ser. 265: 97-105.

Napolitano, G.E., R.J. Pollero, A.M. Gayoso, B.A. Macdonald \& R.J. Thompson. 1997. Fatty acids as trophic markers of phytoplankton blooms in the Bahia Blanca Estuary (Buenos Aires, Argentina) and in Trinity Bay (Newfoundland, Canada). Biochem. Syst. Ecol. 25: 739-755.

Odum, W.E. 1971. Pathways of energy flow in a south Florida estuary. Sea Grant Tech. Bull. Miami Univ. 7: $1-126$.

Odum, W.E. \& E.J. Heald. 1975. The detritus-based food web of an estuarine mangrove community. In L.E. Cronin (ed.). Estuarine Research. Academic, New York.

Parkes, R.J. 1987. Analysis of microbial communities within sediments using biomarkers. Ecology of microbial communities, SGM 41. Cambridge University, Cambridge.

Parrish, C. 1998. Lipid biogeochemistry of plankton, settling matter and sediments in Trinity Bay, Newfoundland. I. Lipid classes. Org. Geochem. 29: 1531-1545.

Parrish, C., C. Abrajano, T.A. Budge, S.M. Helleur, R.J. Hudson, E.D. Pulchan \& C. Ramos. 2000. Lipid and phenolic biomarkers in marine ecosystems: analysis and applications, p. 193-233. In P. Wangersky (ed.). The Handbook of Environmental Chemistry, Part D, Marine Chemistry. Springer Berlin, Heidelberg.

Paulpandian, A.L. \& A. Ramasamy. 1991. In Guide to the prawns of Portonovo. Centre of Advanced Study in Marine Biology, Annamalai University, Parangipettai, India.

Raghukumar, S., S. Sharma, C. Raghukumar, V. SathePathak \& D. Chandramohan. 1994. Thraustochytrid and fungal component of marine detritus. 4. Laboratory studies on decomposition of leaves of the mangrove Rhizophora apiculata Blume. J. Exp. Mar. Biol. Ecol. 183: 113-131.

Rajendran, N. \& K. Kathiresan. 1998. "Mangrove vegetation trap" for improving fishery resources in coastal waters. Curr. Sci. 75: 429-432.
Rajendran, N. \& K. Kathiresan. 1999a. Do decomposing leaves of mangroves attract fishes? Curr. Sci. 77: 972-976.

Rajendran, N. \& K. Kathiresan. 1999b. Seasonal occurrence of juvenile prawn and environmental factors in a Rhizophora mangal, southeast coast of India. Hydrobiologia 394: 193-200.

Rajendran, N. \& K. Kathiresan. 2000. Biochemical changes in decomposing leaves of mangroves. Chem. Ecol. 17: 91-102.

Rajendran, N. \& K. Kathiresan. 2004. How to increase juvenile shrimps in mangrove waters? Wetl. Ecol. Manag. 12: 179-188.

Rajendran, N. \& K. Kathiresan. 2007. Microbes associated with submerged leaf litter of mangroves. Rev. Biol. Trop. 55: 393-400.

Rajendran, N., Y. Suwa \& Y. Urushigawa. 1993. Determination of phospholipid ester-linked fatty acids biomarkers of bacteria in the sediment of Ise Bay. Mar. Chem. 34: 501-514.

Ravikumar, S. 1995. Nitrogen fixing azotobacters from the mangrove habitat and their utility as biofertilizers. Ph.D. Thesis, Annamalai University, Parangipettai, India.

Strom, S.L. 2000. Bacterivory: interactions between bacteria and their grazers, pp. 351-386. In D.L. Kirchman (ed.). Microbial Ecology of the Oceans. Wiley-Liss, New York.

Valiela, I., J.M. Teal, S.D. Allen, R. Van Etten, D. Goehringer \& S. Volkmann. 1985. Decomposition in salt marsh ecosystems: the phases and major factors affecting disappearance of above-ground organic matter. J. Exp. Mar. Biol. Ecol. 89: 29-54.

Volkman, J.K., R.B. Jhons, F.T. Gillan, G.J. Perry \& H.J. Bavour. 1980. Microbial lipids of intertidal sediments. 1. Fatty acids and hydrocarbons. Geochim. Cosmochim. Acta 44: 1133-1143.

Wannigama, G.P., J.K. Volkman, F.T. Gillan, P.D. Nichols \& R.B. Johns. 1981. A comparison of lipid components of the fresh and dead leaves and pneumatophores of the mangrove Avicennia marina. Phytochemistry 20: 659-666. 
